\title{
Offending with Fascism, Or More on the Relevance of History
}

Sergei M. Solovyov

\author{
Sergei M. Solovyov, PhD in Philosophy \\ Lomonosov Moscow State University, Russia \\ Leading Research Fellow; \\ Russian State Archives of Socio-Political History \\ Senior Specialist \\ E-mail: solosm@gmail.com \\ Address: Room 4, Shuvalovsky Building, 27 Lomonosovsky Prospect, Moscow, Russia \\ SPIN RSCI: $8747-4851$ \\ ORCID: 0000-0003-4708-8516 \\ Scopus Author ID: 57211949274
}

DOI: $10.31278 / 1810-6374-2021-19-2-196-207$

This analytical commentary is a response to Marlene Laruelle's article "Accusing Russia of Fascism: Polemics around Russia's Belonging to Europe," published in Russia in Global Affairs, 18(4), 2020, pp. 100-123.

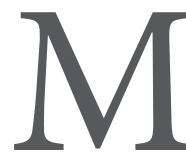
arlene Laruelle's article in Russia in Global Affairs (Laruelle, 2020) addresses current political debate on Russia's role in interest not to argue whether modern Russia can be called "fascist" or if such a discussion can take place at all (in fact, it most certainly can, for it is already in progress: invectives of this sort are voiced both inside and outside Russia), but to talk about the theoretical-or pseudotheoretical-basis of such debates. 
The adjective 'fascist' began to be applied to modern Russia's regime more frequently after Crimea's reincorporation in 2014, and especially after a harder line had been taken towards the non-parliament opposition, especially after the Navalny case at the end of 2020 and the beginning of 2021. Any unbiased onlooker, let alone a scholar, can see well enough that the use of the adjective 'fascist' in relation to modern Russia's political regime is ideological, which Laruelle points out quite correctly in her article.

But it is far more interesting to find out on what facts publicists, propagandists, and historians, who, as M. Kolerov has noted wittingly, take a niche "on the politicized end of historiography" (2018, p. 29), rely in their extremely biased narrative.

The way I see it, such speculations emerge from the gaping void where the theory of 20th century dictatorships was just recently and where the theory of totalitarianism is now in the making. This theory has never been a theory in its own right. Next to this lies a related problem - an utter weakness and vagueness of fascist theories that exist in historiography and social thought. The very fact of this weakness, vagueness and elusiveness creates excellent opportunities for speculations and for the political usage of the word 'fascism' as a swearword and a political label.

The reflections below do not claim to be an extensive theoretical analysis, they are rather a sketch intended to highlight the gravity of the problem in modern studies of the 20th-century history.

Laruelle's article brings up the problem of the wrong usage of the term 'fascism.' As a swearword it has been used for quite a long whilejust shortly after the emergence of fascism as such. The term 'social fascism,' used at the 6th Congress of the Communist International (Comintern) in 1926 in relation to the Social Democrats, was a bright example. But it is worth recalling that the phenomenon of fascism underwent fundamental analysis exactly within the framework of the Comintern, and the works of theoreticians of that time are often cited by modern researchers (Gandesha, 2020). A. Gramsci, K. Radek, Ye. Pashukanis, J. Varga, N. Bukharin and many other Marxist publicists and theoreticians wrote about fascism before World War II. All of them 
regarded Nazism as a variety of fascism. Whatever attitude one may take towards the officially recognized definition that Georgy Dimitrov proposed at the 13th Plenary Session of the Comintern Executive Committee in 1934, it looks serious enough and stands upon a solid theoretical basis. As T. Poulanzas remarked quite correctly, Georgy Dimitrov, in fact, repeated Austrian Marxist Otto Bauer's statement: "While in bourgeois democracy the whole of the bourgeoisie is in power, although under the leadership and domination of big capital, under fascism, big capital and large landowners rule alone" (Poulanzas, 1974, p. 97). A. Gramsci adhered to a similar stance back in 1925. Dimitrov's formula was a replica of a Marxist postulate that had existed for a long time. It was propagandistically polished and consecrated by the name of the Leipzig trial's hero. Although this formula is obviously out of date, it has far more theoretical foundations than one can find in the works of T. Snyder and his followers.

The accusations of Russia's current regime of "fascism" belong with the same class of political labels as the "social fascism" rhetoric of 1928. But they are based on a very concrete politological and ideological tradition of the Cold War era-the theory of totalitarianism as formulated by Z. Brzezinski and K. Friedrich, and not Hannah Arendt, let alone left-wing anti-Stalinists of the late 1920s and early 1930, like Victor Serge (2012).

V. Serge and his proponents used the word 'totalitarianism' primarily as a metaphor to underscore the anti-democratic and counter-revolutionary nature of the Stalinist dictatorship. G. Orwell, who just like Serge, had an experience of personal contact with Stalinist political practices during the Civil War in Spain, also used this term in his works as a metaphor, and then transformed it into imagery in his anti-utopias. But that was not theory.

H. Arendt, who authored her work right after World War II, was well familiar with the German style of dictatorship, but had a very vague idea of the Soviet one. Just like many of her theoretical pieces, The Origins of Totalitarianism is not so much a theoretical treatise as a lengthy essay with embedded historical digressions (a brief history of antisemitism being a particularly graphic example). Z. Brzezinski 
and K. Friedrich, using publicist and artistic metaphors, theoretical sketches and historical essays of different degree of correctness, created a consistent conception, which, however, does not stand up to real facts. The more concrete historical studies of the systems of government, political and repressive apparatuses, and everyday life in Nazi Germany and the Soviet Union emerged, the more obvious it became that the word 'totalitarianism' remains just a politically loaded metaphor, which serious researchers habitually mention in the foreword and afterword of books, or, like the revisionists in U.S. Sovietology, of whom S. Fitzpatrick is currently the brightest representative, reject as it has not become an established term.

French political scientist P. Hassner was quite right when he called totalitarianism "an elusive but indispensable notion" (1999, pp. 226234). This is well seen even in schoolbooks. In the 1990s and the 2000s, the authors of many of them used the theory of totalitarianism to explain the similarities and logic of the emergence of the Soviet regime and right-wing dictatorships in Europe in the first half of the 20th century. After adoption of the "historical-cultural standard," the authors of many schoolbooks stopped applying the term 'totalitarianism' to the Soviet Union but preserved it in descriptions of the regimes in Germany and Italy. In order to understand why this discredited term turned out to be so strangely indispensable, we should recollect the theory of fascism.

It is important to stress that the theory of totalitarianism and the theory of fascism were in conflict with each other after World War II. The development of the fascism theory was perceived as a left-wing trend, while the theory of totalitarianism, as right-of-center criticism of both the Soviet Union and all left-wing ideologies as such (as seeds of the totalitarian ideology). Small wonder, though: the theory of totalitarianism maintained that there were no fundamental distinctions between "leftist" and "rightist" dictatorships and movements (Geyer and Fitzpatrick, 2009, pp. 4-5).

A new wave of politicization amid the current (and far milder) reincarnation of the Cold War is marked by an odd reconciliation of the theory of totalitarianism with the term 'fascism' used as a political 
label. Today this word is increasingly often used in relation to Russia: "totalitarian Russia" or "Russia the inheritor of totalitarianism." Next to this are widely spread attempts at describing Nazism as a left-wing movement (Belous, 2019) - in defiance of many facts, including that Communists and Socialists were declared the main foes of the Duceand Fuhrer-led parties.

There has been a great divergence of opinion over the definitions of fascism ever since the debates on this issue flared up with renewed vigor a quarter of a century ago. Remarkably, just like in the age of antiquity, many authors make no attempts to refute each other; instead they propose their own definitions or refuse to use any clear definitions at all (for instance, the outstanding expert on fascism W. Wippermann (2000, p. 23)).

Many modern researchers have abandoned the class theory as "obsolete." They prefer to describe in great detail the ideological and proto-ideological characteristics of different fascisms, and in doing so they get drowned in self-identifications by members of fascist movements, intricate bundles of their confusing theories, and futile attempts to deconstruct (this word is quite appropriate here) the fascist myths. However, the real purpose of myths is not just telling them but living in accordance with them. The fascist myth, just as any other, is syncretic, irrational and does not imply the possibility of going beyond its own boundaries. (Philosopher N.S. Avtonomova points to the "syncretic nature" of the myth; she views it as an integral combination of several components: aesthetical (imagery), ethical (moral codification-a certain mode of behavior is prescribed for certain conditions), cognitive (identification of certain repeating features of reality)"; and "anti-historicism-atemporal or, otherwise, 'natural' self-assumed character of the myth" (Avtonomova, 1988, pp. 180-181)). For this reason, M. Mann's postulate that fascism should be judged proceeding from its own criteria is fundamentally wrong. It is not accidental that his definition of fascism as "the pursuit of a transcendent and cleansing nation-statism through paramilitarism" (Mann, 2004, p. 13) looks very strange and is not confirmed by his own thorough comparative historical analysis. Mann adheres to the 
standpoint of "methodological empathy," which served as a pillar for the conception of Roger Griffin, probably one of the most well-known experts of fascism. Griffin defined this phenomenon exactly through ideology as a "revolutionary form of nationalism" (Griffin, 1998, pp. 52-53).

Of course, it is essential for us to understand the fascists' mode of thinking, but we are unable to accept their logic and their selfidentification as the truth.

Can a person misjudge one's own position within a social structure? $\mathrm{He} /$ she certainly can. Particularly so in a situation where, in terms of rationality, the entire experience, cultural tradition and everyday common sense, such self-judgement turns out to be traumatic. In this connection, Umberto Eco looks far more correct. He postulates that "one of the characteristics typical of historic Fascist movements was the appeal to the frustrated middle classes, disquieted by some economic crisis or political humiliation, and frightened by social pressure from below" (Eco, 2001, p. 99). It is noteworthy that a number of profound remarks about the nature of fascism were made by a philosopher and author who by no means shuns the term 'totalitarianism,' but prefers to use it in the context of class, not ideology studies.

Attempts to define fascism mostly through ideology, so trendy these days, do not work, precisely because in most fascist movements and in all fascist regimes ideology plays primarily a manipulative role.

While looking for traces of fascism we should proceed not from the mentality of the fascists, not from "methodological empathy," but from specific historical realities: social composition, political functions, economic and political practices, and the aims of fascist movements and regimes.

In contrast to other ideologies that had emerged before fascism, the latter was variegated from the very onset and contained an innate contradiction. Liberalism, conservatism, and social democracy, including its most radical offspring-Communism, all sought a comprehensive analysis of reality.

Fascism essentially lacks this quality. It emerged basically as an ideology that combined elements of social engineering (that is, social 
deceit and manipulation) and grassroots "revolutionary" trends that played a major political role and gave a chance to rise to power only on condition of their use as instruments. It is a combination of these two components-in different proportions, depending on the type of the fascist regime-that produced this phenomenon. Codreanu's fanatic legionnaires, the Strasser brothers-led "left wing" of the Nazi party and Primo de Riviera's Falangists-all were nothing but instruments of their more cynical leaders and failed to become a real political force for any essential period of time. This is an easily identifiable feature of petty bourgeois political movements. Umberto Eco wrote about fascism: "It was not a monolithic ideology, but rather a collage of diverse political and philosophical ideas, a tangle of contradictions. Is it possible to conceive of a totalitarian movement that manages to reconcile monarchy and revolution, the royal army and Mussolini's private militia, the privileges granted the Church and a state education system that extolled violence, total control [not 'total', of course, Eco was a little bit carried away-S.S.], and a free market?” (Eco, 2001, p. 91). He considers Nazism to be more homogenous, but, in fact, Nazism, just like all fascist ideologies, was no less eclectic and inconsistent.

The traditional Marxist scheme, as described by Georgy Dimitrov, put emphasis on the artificial nature and manipulativeness of the fascist regimes, as well as on their tight links with capitalism. It is obviously insufficient for analyzing the origin of fascism, its ideology and political practices. It does not explain why fascist regimes triumphed first and foremost in countries that were of secondary or even tertiary importance in the capitalist world; nor does it explain the reasons for the massiveness of fascist movements when a tremendous number of people, according to Dimitrov, ensure "the dictatorship of the most reactionary, most chauvinistic and most imperialist elements of the financial capital," that is, in fact delegate power to the top brass of the fascist party bureaucracy. On the contrary, most modern theoreticians try to move fascisms away from capitalism as far as possible and play down their links with big business. It looks obvious that in analyzing the phenomenon of fascism it is crucial to bear in mind both socialclass and ideological components. 
Getting back to the interpretations by T. Snyder and other personalities mentioned in Laruelle's article, one should note that they juggle with a random set of features, which the author clearly demonstrates. Even from the standpoint of this classical version of the theory of totalitarianism Russia by no means matches this status, which Laruelle states quite reasonably: “Today's Russia does not offer any criteria that would qualify it as a totalitarian state: there is no system of terror in place, no mandatory indoctrination to subjugate the masses, nor any mobilization mechanisms. Even the qualification of authoritarianism should thus be deployed with nuance in the Russian case. Obviously, public freedoms have been curbed over the last decade, the president may stay in power for life, the electoral options offered by political parties are limited, opponents are hampered in their expression, and the media is increasingly controlled" (Laruelle, 2020, p. 105).

It is also noteworthy that many dictatorships that the United States and its allies still support today, acting according to the formula "...but he is our son of a bitch," match the classical criteria of totalitarianism to a no smaller degree than Iran or North Korea. For instance, Saudi Arabia, Sudan, Eritrea, and even China are not criticized in the U.S. official discourse as strongly as Russia and Belarus are-for quite obvious political reasons.

The theory of totalitarianism provides a platform for such juggling with facts. The classical version of this "theory" is a random set of features, selected mostly because they look bright and are ideologically convenient to use. Such juggling is made possible precisely because history and social philosophy (or historical sociology as its integral part) have been developing very slowly for an essential analysis of the phenomenon of fascism.

In her article Laruelle quite reasonably looks at another side of the problem. In modern Russia fascism is a synonym of absolute evil. The history of the Great Patriotic War is a reference point of national consciousness, and the victory over fascism is a solid argument in favor of Russia's worthy niche in the system of international relations. 
This, in turn, evokes a reverse reaction from some intellectuals in Russia. Claiming that fascism and Nazism are very different has become for some of them a way to distance themselves from officialdom. Meanwhile, for the above-mentioned theoreticians of fascism-R. Griffin, M. Mann, W. Wippermann, and many othersthere is no such problem at all. Here we see not just a rejection of the Soviet model-the standard word combination 'German-fascist' in relation to the history of the Great Patriotic War. From the theoretical point of view this word combination is well-founded.

At the same time, in history books, ideological statements, and academic discussions in Russia the phenomenon of fascism is rather weakly analyzed in theoretical terms. One can even say that Russian authors tend to avoid theoretical analysis of both fascism and Nazism completely, confining themselves to quoting foreign authors. This is a very distinctive feature of modern historical policy in Russia, which does not fit in the "totalitarian" model at all.

Laruelle says: "Thus far, the Kremlin has succeeded in consolidating passive patriotism-passive support for the regime and marginalization of those forces that would contest its authority-but not an active one" (Laruelle, 2020, p. 107).

This "passive patriotism" implies a new noticeable contradiction in official ideology. On the one hand, while insisting on the continuity of Russia's history, its official historical policy is keen to minimize attention to the traumatic moments: revolutions (the obvious wish to silence the 100th anniversary of the 1917 revolution and the 150th anniversary of Vladimir Lenin's birth are bright confirmations of this), acts of repression during the Stalinist period, and some controversial episodes in the history of World War II. On the other hand, safeguarding the official stance, which rests upon allusions to the Great Patriotic War, without studying its controversial and traumatic aspects is impossible: the Ribbentrop-Molotov pact-related problems, the tragedy of prisoners of war, cases of collaborationism and so on surface over and over again, and the Russian historical policy begins to raise these issues ever more often-in "memory wars" the enemies' attacks have to be rebuffed. 
The problem is that fascism as such remains a symbolic figure of silence in Russia's official historical policy. It is regarded as an evil per se, ostensibly requiring no special explanation, and not only explanation but even illustration: until just recently the very image of the swastika has been banned from Russian schoolbooks. In March 2021, the State Duma started considering a bill prohibiting replication of pictures of Nazi leaders (except for educational and research purposes, but, as experience shows, bureaucrats and book publishers prefer to play safe). Amazingly, in Russia no popular science books on fascism have been published, and when one is to name a documentary film about fascism the sole title coming to mind is M. Romm's Ordinary Fascism (also known under the English title Triumph Over Violence) released back in 1965. (Some attempts to improve the situation have been made, though: in 2020, journalist A. Medvedev released a documentary entitled The Great Unknown War (www.youtube.com/watch?v=jrI-wKDXE9k), which blames World War II on Western democracies for allegedly contributing to the rise of fascism in Europe. This film is of little historical value, but it reflects well the current ideological trends of the New Cold War. I must confess I participated in this film myself, but I had no idea of its general concept and now I sincerely regret it.) So, the evil of fascism appears as a sort of ritual figure of silence.

And this figure of silence is not accidental. Any thorough theoretical analysis of the phenomenon of fascism will inevitably require comparison with Stalinism. Meanwhile, in modern Russia there have been frequent calls for banning any attempts to compare (not equate but compare(!)) the Soviet system with Nazism. Yet, as everybody understands, anything can be compared, the comparative method is mandatory in historical studies, and the best modern studies of fascism show this quite clearly. But most importantly, a nonideologized comparison of these two regimes is essential for theoretical assessment of the 20th-century dictatorships, especially if they are made on the basis of the vast amount of facts which continue to be scrutinized by historians and which utterly disagree with primitive theoretical schemes of totalitarianism. 
Thus, Laruelle's article elicits a very important discussion which concerns not so much political science as the relationship between theoretical history, social philosophy, and actual politics. At the beginning of her article Laruelle quotes, quite appropriately, G. Orwell: "As early as 1946, George Orwell observed in Politics and the English Language that 'fascism has now no meaning except in so far as it signifies something not desirable"' (Laruelle, 2020, p. 102). This situation must be changed in both science and politics. For social sciences, in the modern world where, according to such different thinkers as U. Eco (2001, pp. 78, 85) and M. Mann (2004, pp. 372-375), there is a place for the revival of fascism, albeit under a different name, such a theoretical breakthrough would be very important.

The required fundamental rational analysis of the 20th-century historical phenomena has an antagonist-an approach that can be roughly termed "hysterification of history." Timothy Snider is a bright example of it. But in modern Russia, too, proponents of a "hysterical" approach to history are many: quasi-historical programs on many television channels (Zvezda, in particular), thriving conspiracy theories that are welcomed at the official level (Volchkov, 2019), and support for "popular Stalinism" that is also closely related to conspiracy theories, etc.

"Memory wars," however unpleasant to scholars, foment pseudoscientific activity in the genre of hysteria. But this genre is not destined to triumph. Scholars and other specialists in the humanities, however ostentatiously this may sound, are foreordained to go ahead with their mission of resisting it while examining the most traumatic and ideologically loaded events and phenomena of the 20th century.

\section{References}

Avtonomova, N. S., 1988. Rassudok-Razum-Ratsionalnost' [ReasonIntellect-Rationality]. Moscow: Nauka.

Belous, T., 2019. Pochemu Gitler ne byl levym: politichesky spektr i nauchny podhod [Why Hitler Was Not Leftist: Political Spectrum and Academic Approach]. Scepsis [online]. Available at: <scepsis.net/library/id_3910.html> [Accessed 18 March 2021]. 
Eco, U., 2001. Five Moral Pieces. New York, San Diego, London: Harcourt.

Gandesha, S. ( ed.), 2020. Spectres of Fascism. Historical, Theoretical and International Perspectives. London: Pluto Press.

Geyer, M., and Fitzpatrick, S. (eds.), 2009. Beyond Totalitarianism. Stalinism and Nazism Compared. Cambridge University Press.

Griffin, R., 1998. Section II: The Search for the Fascist Minimum: Presentation. In: International Fascism. Theories, Causes and the New Consensus. Bloomsbury Academic.

Hassner, P., 1999. Nasilie i mir. Ot atomnoi bomby do etnicheskoi chistki [Violence and Peace. From Atomic Bomb to Ethnic Purge]. Saint Petersburg: Vsemirnoye slovo.

Kolerov, M., 2018. Totalitarizm. Russkaya programma dlya zapadnoi doktriny [Totalitarianism. The Russian Program for the Western Doctrine]. Moscow: Tsiolkovsky.

Laruelle, M., 2020. Accusing Russia of Fascism. Polemics around Russia's Belonging to Europe. Russia in Global Affairs, 18(4), pp.100-123.

Mann, M., 2004. Fascists. Cambridge University Press.

Poulanzas, T., 1974. Fascism and Dictatorship. The Third International and the Problem of Fascism. London: Verso.

Serge, V., 2012. Memoirs of a Revolutionary. Foreword by A. Hochschild. New York Review Books.

Volchkov, M., 2019. "Istorichesky park" kak ideologicheskoe oruzhie ["Historical Park" as an Ideological Weapon]. Scepsis [online]. Available at: <scepsis.net/ library/id_3879.html> [Accessed 18 March 2021].

Wippermann, W., 2000. Evropeisky fashizm v sravnenii [A Comparative Study of European Fascism]. Novosibirsk: Sibirsky hronograf. 